\title{
Bioremediation of Recalcitrant Textile Azo Dye - Methyl Orange by Bacillus subtilis BRTSI-3 Isolated from Textile Effluents
}

\author{
M. Meenatchi ${ }^{1}$, K. Shilpa ${ }^{1}$, D. Nithya ${ }^{1}$, K. Soniya ${ }^{1}$, S. Sunila ${ }^{1}$, S. Nandhini ${ }^{1}$, \\ Kayeen Vadakkan ${ }^{2}$, A. Vidhya ${ }^{1}$, S. Ramya ${ }^{1}$ and J. Hemapriya ${ }^{1 *}$
}

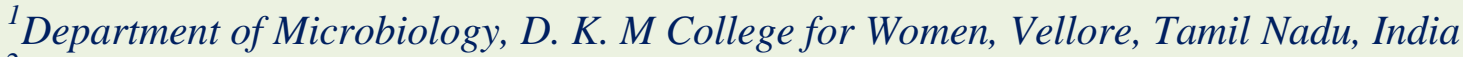

${ }^{2}$ Bioresource Technology Lab, Department of Biotechnology, Thiruvalluvar University, Vellore, Tamil Nadu, India

*Corresponding author

\begin{abstract}
A B S T R A C T
\section{Keywords}

Azo Dyes, Bacillus subtilis, Decolorization, Effluent, Methyl orange

Article Info

Accepted:

25 June 2018

Available Online:

10 July 2018

Textile effluent samples collected from dye contaminated area of Ranipet, Vellore have been used for isolating bacterial strains. Among various bacterial isolates, BRTSI-3 was selected and was further characterized using morphological and biochemical analysis. $16 \mathrm{~S}$ rDNA sequencing confirmed the strain BRTSI3 as Bacillus subtilis (NCBI accession number MH412808). The culture conditions for maximizing bacterial biomass were found to be optimized at $35^{\circ} \mathrm{C}$ and $\mathrm{pH}$ 8.0. Bacillus subtilis effectively decolorized methyl orange in nutrient broth within $48 \mathrm{~h}$ of incubation. Spectrometric methods such as UV- Vis spectrophotometry and FTIR were used for assessing the decolorization extent of methyl orange by BRTSI3. FTIR results confirmed the breakdown of methyl orange by bacterial metabolites. The investigation proved that the microorganisms found in textile effluent are capable of decolorizing and degrading the azo compounds of textile effluent.
\end{abstract}

\section{Introduction}

Colors play a major role in day to day life. To fulfill the need of the customers, commodities are colored in different shades and patterns. Dyes and dyestuffs were used to impart color in pharmaceutical, textile and food industries (Ayed et al., 2011). More than 10,000 dyes are commercially available in the market. About $60 \%$ of commercially available dyes are azodyes. Azo dyes are distributed in three different classes namely monoazo, diazo and triazo (Weber and Adams, 1995). These dyes are considered to be highly recalcitrant molecules, as they are very difficult to degrade by microorganisms and as a result, pose a serious threat to environment leading to water and soil pollution affecting flora and fauna.

About $10-15 \%$ of dyes used in textile industries do not fix to the fibers, and discharge as waste into the treatment plant or into the environment directly and causes environmental pollution (Cetin et al., 2008). Higher organic or inorganic load with intense heat, color, alkali or acidic nature of the effluent convert them into highly recalcitrant.

Numerous literature sources provide us knowledge about removal of azodyes by the 
means of physical, chemical and biological methods. Microorganisms were found to be the ideal candidates in the field of bioremediation. Microbes such as fungi, algae, bacteria and actinomycetes were used as an alternative for physio-chemical treatment methods. Bioremediation has proved to a feasible process for removal of hazardous dye from the ecosystem. According to Jadhav et al., (2008), microbial consortium containing Bacillus sps. and Galactomyces geotrichum showed effective degradation of Brilliant blue $\mathrm{G}$ dye. Bacillus species was reported to decolorize methyl orange effectively (Ali, 2005).

Detoxification studies including phytotoxicity and microbial toxicity assay also proved that the degraded compounds are nontoxic when compared to the parental azo compounds (Parshetti et al., 2010). Work done by Shah et al., (2013) proved that Pseudomonas sps was found to decolorize methyl orange efficiently and also proved that the strain can tolerate higher concentration of dye which makes them a right choice for their exploration in the textile effluent treatment plant. In the present study, bacterial strain isolated from effluent sample of textile industry was characterized by morphological, biochemical and molecular sequencing (16SrRNA). The efficacy of isolate in decolorizing methyl orange was performed quantitatively by using UV-Vis spectrophotometry and FTIR analysis.

\section{Materials and Methods}

\section{Sampling Sites}

The sampling area in this study was the textile industries and dyeing units located in and around Arani, Thiruvannamalai District, Tamil Nadu, India. The effluent samples from both textile industries and dyeing units were characterized by its dark color and extreme turbidity.

\section{Azo Dye Used}

The commonly used textile azo dye, Methyl Orange used in this study was procured from a local textile dyeing unit. Stock solution was prepared by dissolving $1 \mathrm{~g}$ of azo dye in 100 $\mathrm{ml}$ distilled water. The dye solution was sterilized by membrane filtration. All the chemicals used in this study were of the highest purity available and of an analytical grade.

\section{Isolation and Screening of Bacterial Strains Decolorizing Methyl Orange}

The effluent samples were serially diluted and spread over nutrient agar medium containing $50 \mathrm{ppm}$ of azo dye. $\mathrm{pH}$ was adjusted to 7.0 before autoclaving and incubated at $37^{\circ} \mathrm{C}$ for 5 days. Colonies surrounded by halo (decolorized) zones were picked and streaked on nutrient agar plates containing azo dyes. The plates were re-incubated at $37^{\circ} \mathrm{C}$ for 3 days to confirm their abilities to decolorize Methyl Orange.

\section{Decolorization Assay using UV-visible spectrophotometer}

A loopful of bacterial culture was inoculated in $100 \mathrm{ml}$ of nutrient broth and incubated at $150 \mathrm{rpm}$ at $37^{\circ} \mathrm{C}$ for $24 \mathrm{~h}$. Then, $1 \mathrm{ml}$ of $24 \mathrm{~h}$ old culture of BRTSI 3strain was inoculated in $100 \mathrm{ml}$ of nutrient broth containing $50 \mathrm{ppm}$ of Methyl Orange and re-incubated at $37^{\circ} \mathrm{C}$ till complete decolorization occurs.

Suitable control without any inoculum was also run along with experimental flasks. 1.0 $\mathrm{ml}$ of sample was withdrawn every $12 \mathrm{~h}$ and centrifuged at $10,000 \mathrm{rpm}$ for $15 \mathrm{~min}$. Decolorization extent was determined by measuring the absorbance of the culture supernatant at $470 \mathrm{~nm}$ respectively, using UVvisible spectrophotometer, according to Hemapriya et al., (2010). 
Decolorization efficiency $(\%)=$ Dye $(\mathrm{i})-$ Dye (r) / Dye (i) X 100

Where, Dye (i) refers to the initial dye concentration and Dye (r) refers to the residual dye concentration. Decolorization experiments were performed in triplicates.

\section{Characterization and 16S rDNA Analysis of BRTSI-3 strain}

Strain BRTSI-3 was characterized morphologically and biochemically according to Bergey's manual of systemic bacteriology. The 16S rDNA sequence of the isolates were amplified via the polymerase chain reaction (PCR), using two universal primers: the $16 \mathrm{~S}$ forward primer and the $16 \mathrm{~S}$ reverse primer, which yielded a product of approximately 1.5 $\mathrm{kb}$. The purified PCR product was directly sequenced using Big Dye Terminator version 3.1 cycle sequencing kit. The nucleotide sequence analysis was done at BLAST-n site at NCBI server www.ncbi.nlm.nih.gov/BLAST. The alignment of the sequences was done using CLUSTAL W program VI.82 at European Bioinformatics site (www.ebi.ac.uk/clustalw). The analysis of 16S rDNA gene sequence was done at Ribosomal Data Base Project (RDP) II (http://rdp.cme.msu.edu). The phylogenetic tree was constructed using the aligned sequences by the neighbour joining method using kimura-2 parameter distances in MEGA 2.1 software.

\section{Optimization of culture conditions}

$100 \mathrm{ml}$ of nutrient broth was inoculated with loopful culture of BRTSI-3 in different conical flasks. All the flasks were incubated at different $\mathrm{pH}(4,5,6,7,8$ and 9) and different temperature ranges $(20,25,30,35,40,45$ and $50{ }^{\circ} \mathrm{C}$ ) for $24 \mathrm{~h}$. Following incubation, the bacterial growth was monitored in above mentioned flasks to check the optimum $\mathrm{pH}$ and temperature for maximizing bacterial biomass. The optimum culture condition where maximum growth was observed and was maintained for further studies.

\section{FTIR Analysis of Decolorized Samples}

The biodecolorized azo dye samples were characterized by FTIR spectroscopy (JASCO). The analysis results were compared with the control dye. The FTIR analysis was done in the mid IR region $\left(400-4000 \mathrm{~cm}^{-1}\right)$ with 16 scan speed. The samples were mixed with spectroscopically pure $\mathrm{KBr}$ in the ratio (5:95). The pellets were fixed in sample holder and then analyzed (Saratale et al., 2009).

\section{Results and Discussion}

\section{S rDNA Analysis of BRTSI-3 Strain}

BRTSI-3 strain exhibited remarkable efficiency in decolorizing methyl yellow (Fig 1). The morphological and biochemical characteristics of the strain BRTSI-3 that exhibited maximum decolorization efficiency towards Methyl Orange is shown in Table 1. A total of 1153 bases sequence of PCR amplified 16S rDNA gene was determined from the isolate BRTSI-3.

In the phylogenetic analysis, the sequence formed a cluster with in Bacillus sps with 92 $\%$ identity, thus confirming the isolate as Bacillus subtilis Strain BRTSI-3 (Fig. 2) and phylogenetic tree constructed was shown in Fig. 3. The obtained sequence was submitted to GenBank with the accession number MH412808.

\section{Growth optimization: Influence of temperature and $\mathrm{pH}$}

Incubation time played a significant role in maximizing the biomass of Bacillus sp. strain BRTSI-3. 
Fig.1 Decoloization of Methyl Orange by BRTSI-3 Strain (Control and Test Sample)

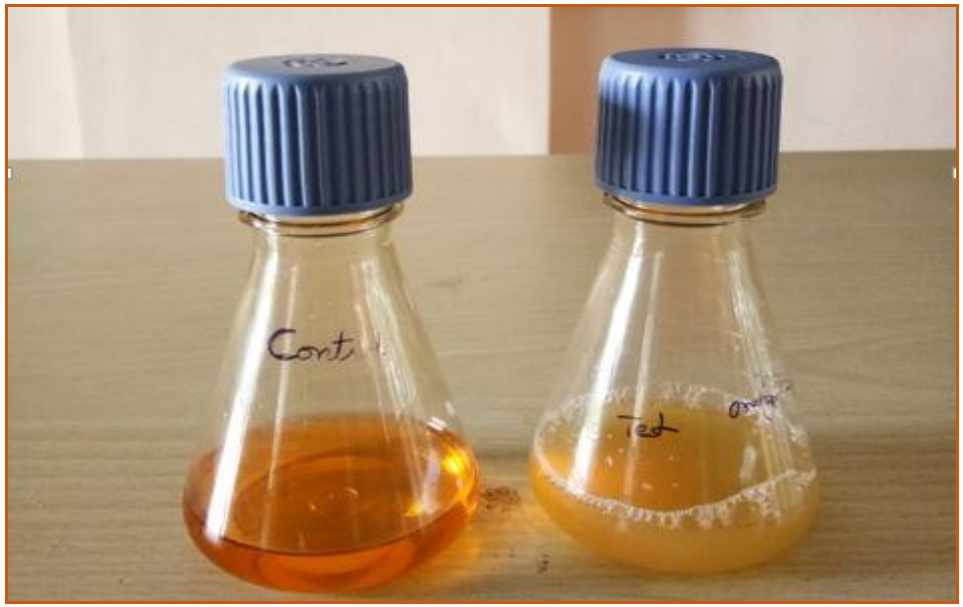

Fig.2 PCR amplified 16S r RNA sequence of the isolate BRTSI-3

>CONTIG B
TCGACCGGAAGGATGGGAGCTTGCTCCCTAATGTTAGCGGCGGACGGGAGAGTAA
CACGTGGGTCACCTGCCTGTAAGACTGAGATAACTCCGGGAAACCGGGGCTAATA
CCGGATGGTTGTTGAACCGCATGGTTCGAACATAAAATGTGGCTTCGGCTACCAC
TTACACATGGACCCGCGGCGCATTAGCTAGTTGGTGAGGTAATGGCTCACCAAGG
CAACGATGCGTAGCCGACCTGAGAGGGTGATCGGCCACACTGGGACTGAGACACG
GCCCAGACTCCTACGGGAGGCAGCAGTAGGGAATCTTCCGCAATGGACAAAAGTC
TGACGGAGCAACGCCGCGTGAGTGATGAAGGTTTCGGATCGTAAAGCTCTGTTG
TTAGGGAAGAACAAGTACCGTTCGAATAGGGCGGTACCTTGACGGTACCTAACCA
GAAAGCCACGGCTAACTACGTGCCAGCAGCCGCGGTAATACGTAGGTGGCAATCG
TTGTCCGGAATTATTGGGCGTAAAGGGCTCGCAGGCGGTTTCTTAAGTCTGATGTG
AAAGCCCCCGGCTCAACCGGGGAGGGTCATTGGAAACTGGGGAACTTGAGTGCAG
AAGAGGAGAGTGGAATTCCACGTGTAGCGGTGAAATGCGTAGAGATGTGGAGGA
ACACCAGTGGCGAAGGCGACTCTCTGGTCTGTACTGACGCTGAGGAGCGAAAGCG
TGGGGAGCGAACAGGATTAGATACCCTGGTAGTCCACGCCGTAACGATGAGTGCT
AAGTGTTAGGGGTTCCGCCCTTATGCTGCAGCTAACGCATTAGCACTCCTCTGGGG
AGACAGTCGCAGACTGAAATCAAGGAATTGACGGGGGCCCCACAACCGTGGAGAT
GTGGTTAATTCGAGCACGCGAAAACCTTACAGGTCTGACACCTCTGACATCTAAA
AAAGGACGTCTCTTCGGGGCAAATGACAGTGTGCATGGTGTCGTCGCTCAGTCCG
AAATGTGGGTTAGTCCCCACAACGCGCCCTGATCTAGTGCCGCATCATTGGGCCTC
TAAGGGATGCCGGACAACCGGAGGAGGGGGGAGACTCCATTTCTTGCCCTTTGAC
TGGGTACCCGGCTCATGGACAACAAAGGGGCGAACCCGGGTAGCCATCCC

Fig.3 Phylogenetic tree of the isolate BRTSI-3

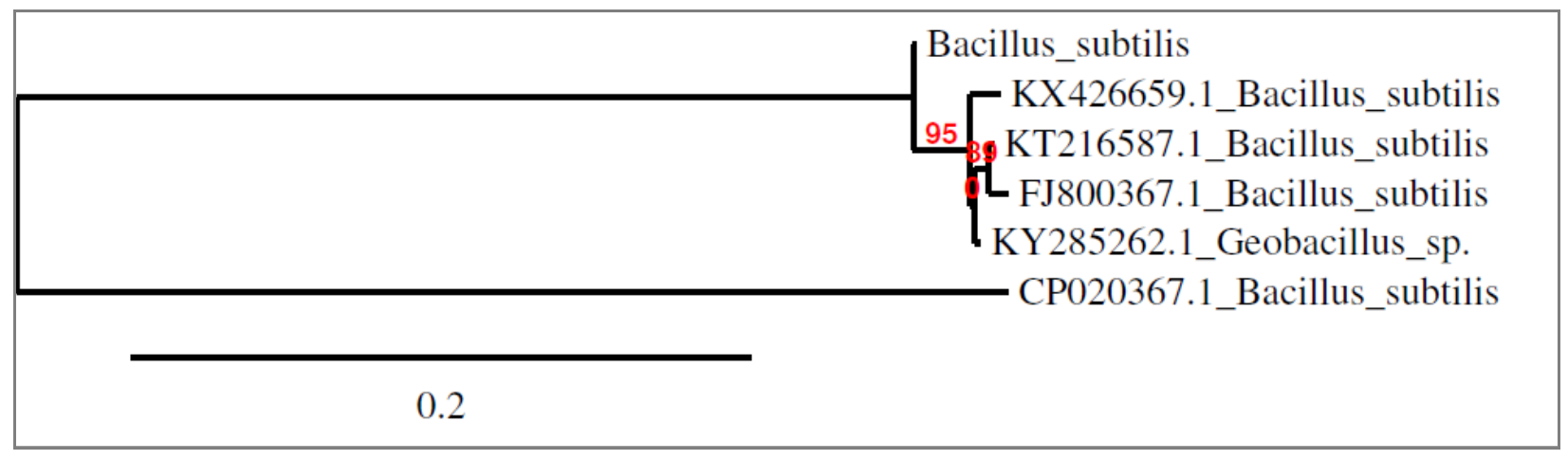


Fig.4 Effect of Temperature on the biomass of Bacillus subtilis strain BRTSI-3

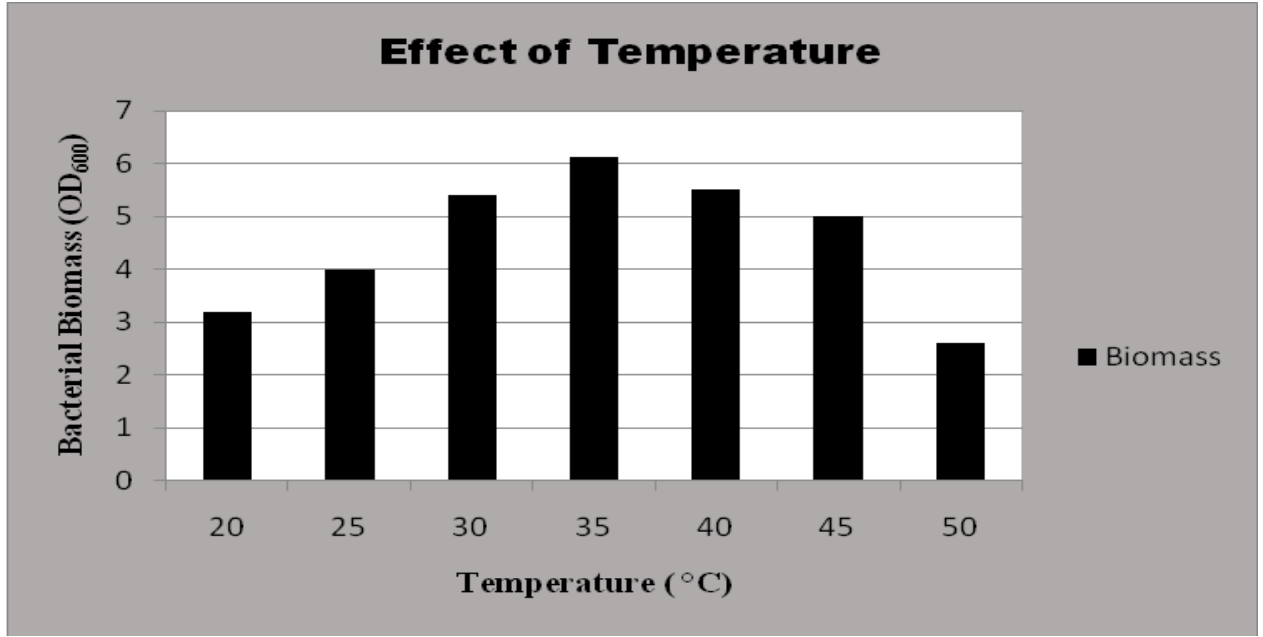

Fig.5 Effect of $\mathrm{pH}$ on the biomass of Bacillus subtilis strain BRTSI-3

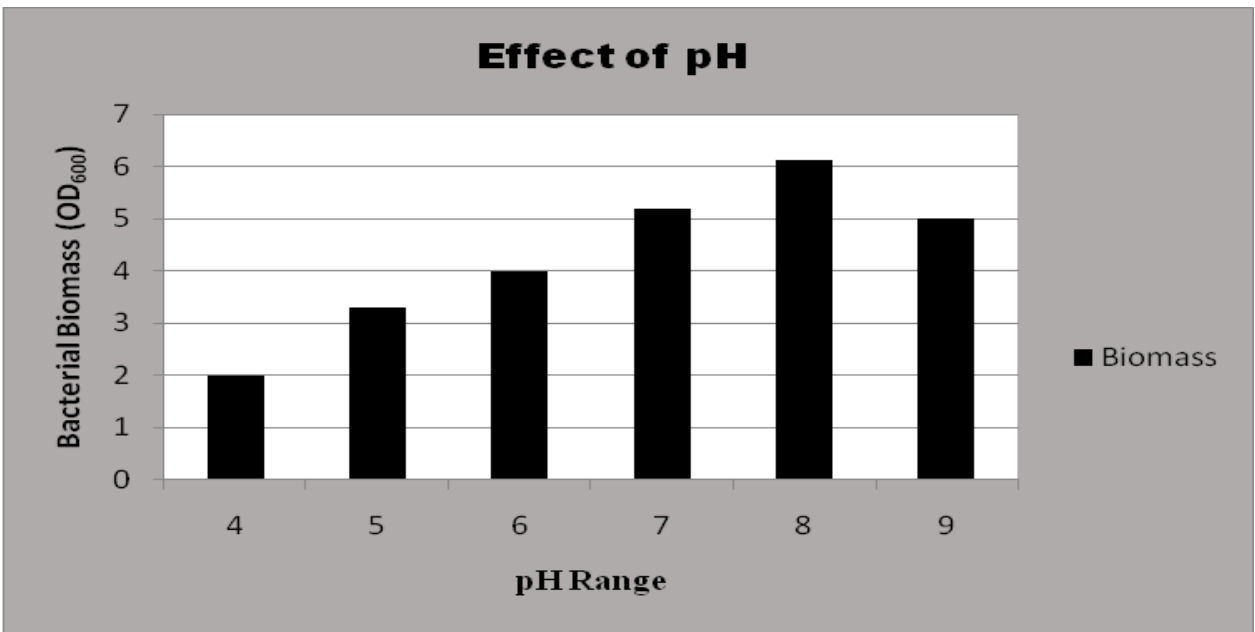

Fig.6 FT-IR spectra of decolorized Methyl Orange

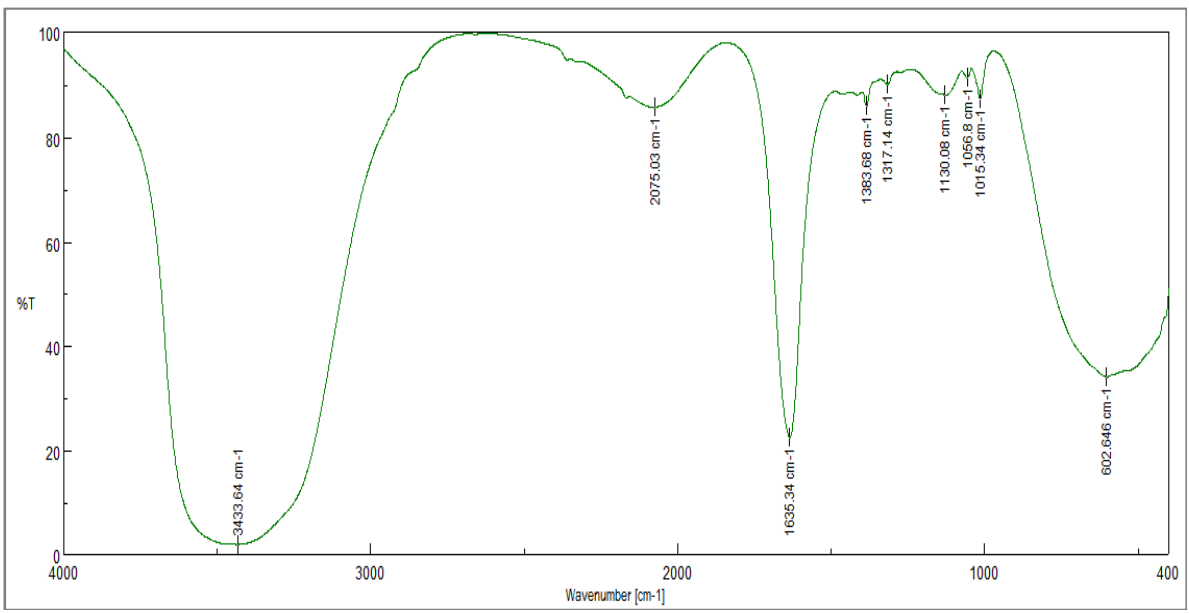


Table.1 Morphological, Physiological and Biochemical Characteristics of strain BRTSI-1

\begin{tabular}{|c|c|c|}
\hline S. No & Test & Observations \\
\hline 1 & $\begin{array}{l}\text { Morphology } \\
\text { Grams staining } \\
\text { Cell shape and arrangement } \\
\text { Motility }\end{array}$ & $\begin{array}{l}\text { Positive } \\
\text { Rods arranged singly/pairs } \\
\text { Motile }\end{array}$ \\
\hline 2 & $\begin{array}{l}\text { Colony Characters on Nutrient agar } \\
\text { Colony morphology } \\
\text { Colony size } \\
\text { Colony elevation } \\
\text { Colony edge } \\
\text { Pigmentation }\end{array}$ & $\begin{array}{l}\text { Round } \\
2-2.5 \mathrm{~mm} \\
\text { Raised } \\
\text { Entire } \\
\text { Nonchromogenic }\end{array}$ \\
\hline 3 & $\begin{array}{l}\text { Sugar Fermentation } \\
\text { Lactose } \\
\text { Maltose } \\
\text { Sucrose }\end{array}$ & $\begin{array}{l}\text { Positive-Acid } \\
\text { Positive-Acid } \\
\text { Positive-Acid }\end{array}$ \\
\hline 4 & $\begin{array}{l}\text { Enzyme Reaction } \\
\text { Urease Production } \\
\text { Nitrate Reductase } \\
\text { Oxidase } \\
\text { Coagulase } \\
\text { Catalase Activity }\end{array}$ & $\begin{array}{l}\text { Negative } \\
\text { Positive } \\
\text { Negative } \\
\text { Negative } \\
\text { Positive }\end{array}$ \\
\hline 5 & $\mathrm{H}_{2} \mathrm{~S}$ Production & Positive \\
\hline 6 & Gelatin & Positive (24 h) \\
\hline
\end{tabular}

Temperature was found to be directly proportional to bacterial growth till $35^{\circ} \mathrm{C}$ and inversely proportional to bacterial growth above $35^{\circ} \mathrm{C}$. Thus, maximum growth was observed at $35^{\circ} \mathrm{C}$. Optical density was found to be 0.56 at $610 \mathrm{~nm}$ (Fig. 4). Temperature level above and below $35{ }^{\circ} \mathrm{C}$ drastically reduced the bacterial growth. However, growth rate of BRTSI-3 strain gradually increased with increase in $\mathrm{pH}$ level, reaching its maximum growth (biomass) at $\mathrm{pH} 8.0$ whereas, the bacterial growth was found to be reduced at $\mathrm{pH}$ level greater than 8.0 (Fig. 5).

\section{Decolorization studies using UV-VIS spectrophotometry}

Visible color change was observed in the test flask after $24 \mathrm{~h}$ of incubation, which may be either due to biosorption or degradation of methyl orange present in the culture media. The Test and Control sample was centrifuged at $4000 \mathrm{rpm}$ for about $15 \mathrm{~min}$ and the resultant supernatant was subjected for UVVisible spectroscopy. Absorbance peaks of control and decolorized sample evidently showed the decolorization of methyl orange.

\section{FTIR analysis}

FTIR analysis enables to study the degradation of methyl orange by bacterial metabolites (Fig. 6). This study clearly indicated the interaction of bacterial molecules in degrading azo dye methyl orange. O-H stretch at $3433 \mathrm{~cm}^{-1}$ indicates the presence of carboxylic acid group. Vibration at $1635 \mathrm{~cm}^{-1}$ denotes the presence of amide class of compounds. Stretches between 1317 $\mathrm{cm}^{-1}$ to $1015 \mathrm{~cm}^{-1}$ represents the presence of 
alkyl halides (C-F stretch). Degradation of methyl orange was confirmed by referring the control peaks reported by Chen et al., (2008).

Economically feasible and eco-friendly strategies are inevitably required to degrade dye-contaminated wastewater discharged from various industries. In the present study, bacterial strain BRTSI-3 isolated from textile effluent sample was characterized by means of morphological, biochemical and 16S rDNA sequencing. The strain BRTSI-3 was found to be Bacillus subtilis (NCBI accession number MH412808). The bacterial growth was found to be optimized at $35^{\circ} \mathrm{C}$ and $\mathrm{pH}$ 8.0. The bacterial culture was inoculated in nutrient broth with methyl orange for detecting the degradation rate. UV-Vis spectrophotometry results indicated the decolorization of methyl orange by bacterial metabolites. FTIR results confirmed the breakdown of the azo dye by bacterial metabolites. Thus this work may provide a reasonable basis for development of an effective bioremediation process for the safe remediation of dye pollutants present in textile effluents.

\section{References}

Ali, A., 2005. Decolorization of Methyl Orange (As a Model Azo Dye) by the Newly Discovered Bacillus Sp. Iran. J. Chem. Chem. Eng. 24, 41-45.

Ayed, L., Mahdhi, A., Cheref, A., Bakhrouf, A., 2011. Decolorization and degradation of azo dye Methyl Red by an isolated Sphingomonas paucimobilis: Biotoxicity and metabolites characterization. DES 274,
272-277. https://doi.org/10.1016/j.desal.2011.02.024

Cetin, D., Donmez, S., Donmez, G., 2008. The treatment of textile wastewater including chromium(VI) and reactive dye by sulfatereducing bacterial enrichment,. J. Environ.Manage. 88, 76-82.

Chen, Y., Liu, S., Yu, H., Yin, H., Li, Q., 2008. Chemosphere Radiation-induced degradation of methyl orange in aqueous solutions. Chemosphere. 72, 532-536.

Hemapriya, J., Rajeshkannan, V., Vijayanand., 2010. Bacterial decolorization of Direct Red-28 under aerobic conditions. J. Pure Appl. Microbiol., 4(1): 309-314.

Jadhav, S.U., Jadhav, M.U., Kagalkar, A.N., Govindwar, S.P., 2008. Decolorization of Brilliant Blue $G$ dye mediated by degradation of the microbial consortium of Galactomyces geotrichum and Bacillus sp. J. Chinese Inst. Chem. Eng. 39, 563-570. https://doi.org/ 10.1016/j.jcice.2008.06.003

Khan, S., Mathur, N., 2015. Biodegradation of Different Dye by Bacterial Strains Isolated from Textile Effluents of Western Rajasthan, India. Int.J.Curr.Microbiol.App.Sci. 4, 994-1001.

Parshetti, G.K., Telke, A.A., Kalyani, D.C., Govindwar, S.P., 2010. Decolorization and detoxification of sulfonated azo dye methyl orange by Kocuria rosea MTCC 1532. J. Hazard. Mater. 176, 503-509.

Shah, M.P., Patel, K.A., Nair, S.S., Darji, A.M., 2013. Microbial decolourization of methyl orange dye. Biochem. Eng. Bioprocess Eng. $2,1-7$.

Weber, E.J., Adams, R.L., 1995. Chemical- and sediment-mediated reduction of the azo dye Disperse Blue 79, Environ. Sci. Technol. $29,1163-1170$.

\section{How to cite this article:}

Meenatchi M., K. Shilpa, D. Nithya, K. Soniya, S. Sunila, S. Nandhini, Kayeen Vadakkan, A. Vidhya, S. Ramya and Hemapriya J. 2018. Bioremediation of Recalcitrant Textile Azo Dye Methyl Orange by Bacillus subtilis BRTSI-3 Isolated from Textile Effluents. Int.J.Curr.Microbiol.App.Sci. 7(07): 4361-4367. doi: https://doi.org/10.20546/ijcmas.2018.707.508 